\title{
ПАРАМЕТРИ ЯКОСТІ ЖИТТЯ У ХВОРИХ НА ГІПЕРТОНІЧНУ ХВОРОБУ ІІ СТАДІї
}

\author{
Ж. С. Шомоді, О. П. Венгер \\ Берегівська обласна психіатрична лікарня \\ ДВНЗ «Тернопільський державний медичний університет \\ імені І. Я. Горбачевського МОЗ Украӥни»
}

У статті викладено сучасні дані щодо визначення параметрів якості життя у хворих на гіпертонічну хворобу II ступеня та їх гендерні особливості.

\section{PARAMETERS OF LIFE QUALITY IN PATIENTS WITH ARTERIAL HYPERTENSION STAGE 2}

\author{
Z. S. Shomodi, O. P. Venher \\ Berehovo Regional Psychiatric Hospital \\ I. Horbachevsky Ternopil State Medical University
}

The article presents current data on the determination of life quality parameters in patients with hypertension stage 2 and their gender characteristics.

Вступ. Артеріальна гіпертензія (АГ) займає перше місце за поширеністю серед хронічних неінфекційних захворювань у більшості країн світу. Близько $90 \%$ артеріальної гіпертензії становить гіпертонічна хвороба (ГХ), що діагностується в Україні в $40 \%$ жінок та 39 \% чоловіків [1]. Ії̈ускладнення мають значну питому вагу в структурі причин смертності та інвалідизації населення України.

Водночас до найпоширеніших хвороб належить ожиріння. Варто зауважити, що ожиріння як глобальна епідемія, на даний час спостерігається як у розвинутих країнах, так і в країнах, що розвиваються $[2,3]$. Надмірну масу тіла у світі мають близько 1,7 млрд осіб, серед них хворі на ожиріння становлять 320 млн, а у Європі ці показники становлять 400 млн та 130 млн відповідно [4].

В Україні, за оцінками ВООЗ, надмірну масу тіла мають 50,5 \% чоловіків, з них 16 \% хворіють на ожиріння, і 56 \% жінок, у 26 \% з яких діагностовано ожиріння [5].

Паралельно з гіпертензією психічні розлади також становлять значний тягар для здоров'я. Депресивні та тривожні розлади (наприклад, панічний розлад і генералізований тривожний розлад) $є$ найчастіше діагностованими [6]. Кілька метааналітичних дослі() Ж. С. Шомоді, О. П. Венгер, 2018 джень показали, що розлади настрою збільшують ризик розвитку серцево-судинних захворювань в геометричній прогресії [7].

Мета дослідження - вивчити провідні чинники, які впливають на якість життя хворих на ГХ ІІ стадії.

Основна частина. У дослідження було включено 30 пацієнтів середнього віку (44-60 років) із діагнозом ГX ІІ стадії, 2-го ступеня (рівень артеріального тиску менше 180/110, але більше 159/99 мм рт. ст.

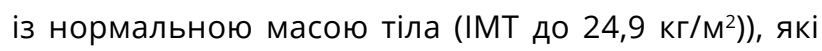
перебували на амбулаторному лікуванні у поліклінічному відділенні Берегівської центральної районної лікарні імені Берталона Ліннера. Для оцінки якості життя використано коротку версію Опитувальника здоров'я-36 (МОC-36 - Short-Form Health Survey, або MOS SF-36), розробленого в США, на основі інших, вже існуючих тестів [8]. Він дозволяє оцінювати задоволеність пацієнтів своїм фізичним, психічним і соціальним функціонуванням за допомогою 8 шкал і 36 питань. Ці шкали можуть бути умовно поділені на 2 групи: 1 - фізична (4 шкали) і 2 - розумова (4 шкали). 1 група включає такі шкали: фізичне функціонування (ФФ) - самообслуговування і самостійне пересування з різними навантаженнями; рольове фізичне функціонування (РФФ) - повсякденна і професійна робота 
залежно від фізичного дефекту; тілесний біль (ТБ) самооцінка інтенсивності больового синдрому і його впливу на повсякденну і професійну роботу; загальне здоров'я (33) - самооцінка свого здоров'я на даний час і в перспективі.

2 група включає шкали: життєздатність (Ж3) - відчуття енергії, сил або, навпаки, ослаблення, знесилення, втомленості; соціальне функціонування (СФ) задоволення рівнем своєї соціальної діяльності; рольове емоційне функціонування (РЕФ) - обмеження виконання повсякденної й професійної роботи залежно від емоційної лабільності, нестійкості; психічне здоров'я (ПЗ) - самооцінка настрою спокою, позитивних емоцій або, навпаки, занепокоєння, депресії, горя.

У результаті порівняльного аналізу було виявлено вірогідне зниження якості життя у хворих, на відміну від практично здорових осіб, за усіма параметрами. Параметр фізичного функціонування у хворих на ГХ достовірно знизився на 44,3 \% порівняно з нормативом якості життя здорових людей. Зниження показника в шкалі фізичного функціонування зумовлює і його зниження в шкалі рольового фізичного функціонуван- ня на 20,6 \% як відображення порушення у виконанні повсякденної та професійної роботи.

Достовірне зниження ж параметрів за шкалами рольового емоційного функціонування на 21,8 \%, загального здоров'я і життєздатності на 44,1 \% є наслідком розвитку негативних емоцій, тривожності та депресії, що відображається в шкалі психічного здоров'я падінням ії показника на 29,0%. Незважаючи на досить виражену невротизацію, більшість пацієнтів демонструють порівняно невелику ступінь обмеження щоденної (домашньої) і трудової діяльності внаслідок емоційної нестійкості. Як загальний наслідок порушень психічного і фізичного здоров'я відбувається зниження параметра соціального функціонування на 37,6 \%. Інтегративний параметр (QL) падає на 36,7 \%. Недостатня ефективність терапії та песимістична перспектива лікування призводять до розвитку невротизації, занепокоєння, синдрому «занурення у хворобу» і невпевненості щодо перспектив життя. Це негативно відображається на суб'єктивній самооцінці хворого на ГХ і його ставленні до життєвих ситуацій (табл. 1).

\section{Таблиця 1. Параметри якості життя пацієнтів із гіпертонічною хворобою II стадії}

\begin{tabular}{|c|c|c|}
\hline Назва шкали & $\begin{array}{c}\text { Норматив якості життя } \\
\text { практично здорових людей }\end{array}$ & $\begin{array}{c}\text { Параметри якості життя осіб } \\
\text { із ГХ ІІ стадії } \\
\end{array}$ \\
\hline Фізичне функціонування & $90,5 \pm 1,2$ & $\begin{array}{c}50,4 \pm 3,2 \\
p<0,05\end{array}$ \\
\hline Рольове фізичне функціонування & $75,7 \pm 2,0$ & $\begin{array}{l}60,1 \pm 2,5 \\
p<0,05\end{array}$ \\
\hline Шкала болю & $80,1 \pm 0,9$ & $\begin{array}{l}47,4 \pm 2,9 \\
p<0,05\end{array}$ \\
\hline Загальне здоров'я & $70,2 \pm 3,4$ & $\begin{array}{l}39,2 \pm 3,0 \\
p<0,05\end{array}$ \\
\hline Життєздатність & $74,3 \pm 3,6$ & $\begin{array}{l}41,1 \pm 1,9 \\
p<0,05\end{array}$ \\
\hline Соціальне функціонування & $80,5 \pm 2,2$ & $\begin{array}{c}50,2 \pm 1,5 \\
p<0,05\end{array}$ \\
\hline Рольове емоційне функціонування & $77,8 \pm 1,2$ & $\begin{array}{l}60,8 \pm 1,7 \\
p<0,05\end{array}$ \\
\hline Психічне здоров'я & $67,5 \pm 1,6$ & $\begin{array}{l}47,9 \pm 2,0 \\
p<0,05\end{array}$ \\
\hline Інтегративний параметр & $70,8 \pm 2,5$ & $\begin{array}{l}44,8 \pm 1,5 \\
p<0,05\end{array}$ \\
\hline
\end{tabular}

Примітка: р - різниця достовірна порівняно з практично здоровими людьми.

При порівнянні якості життя в групі хворих між чоловіками та жінками було виявлено значущі відмінності всіх досліджуваних параметрів за Опитувальником SF-36. При цьому найвиразніше зниження спостерігали у параметрах болю - на 60 \% (p<0,05), рольового фізичного - на $50 \%(p<0,05)$, рольового емоційного - на $49 \%(p<0,05)$ та соціального функціонування - на $42 \%$ ( $<<0,05)$. Життєздатність, загальне та психічне здоров'я, фізичне функціонування різнилися менш істотно - на $27 \%(p<0,05), 22 \%(p<0,05)$, $21 \%(p<0,05), 19 \%(p<0,05)$ відповідно. Виявлені зміни якості життя у жінок вказують на те, що ГХ не тільки 
зумовлюєпідвищення кардіоваскулярного ризику, але й заважає їм відчувати себе здоровими. За даними анкети В. П. Зайцева, більшість хворих на ГХ вказала на погіршення якості життя у зв'язку з повсякденними обмеженнями - 52,2 \%. Потреба у зверненні за допомогою до лікаря та лікуванні позначається на повноцінному житті 38,8 \% пацієнтів (ДІ 28,3-50,0). Частка жінок, які мали вказані чинники, була вірогідно більшою. Зміни у статевому житті зазначили 25,4 \% хворих незалежно від статі.

Логічно припустити, що зниження якості життя серед жінок значною мірою зумовлене особливостями перебігу ГХ. Так, частка пацієнтів із безсимптомним перебігом серед чоловіків була достовірно більшою 40,6 \%, тоді як серед жінок вона склала лише 10,8 \%. У той же час, головний біль спостерігали у 80,0 \% жінок

\section{СПИСОК ЛІТЕРАТУРИ}

1. Рекомендації Української Асоціації кардіологів з профілактики та лікування артеріальної гіпертензії : посібник до Національної програми профілактики і лікування артеріальної гіпертензії. - К. : ПП ВМБ, 2008. - 80 с.

2. Bradshaw T. Obesity and serious mental ill health: A critical review of the literature / T. Bradshaw, H. Mairs // Healthcare. - 2014. - Vol. 2. - P. 166-182.

3. Корниенко Е. А. Ожирение и кишечная микробиота: современная концепция взаимосвязи / Е. А. Корниенко, О. К. Нетребенко // Педиатрия. - 2012. - Т. 91, № 2. C. $110-122$.

4. Москаленко В. Ф. Формування глобальної комплексної інтегральної міжсекторальної системи профілактики інноваційний підхід до вирішення сучасних проблем громадського здоров'я (огляд літератури та власних досліджень) / В. Ф. Москаленко // Журнал АМН України. 2009. - Т. 15, № 3. - С. 516-542.

5. Приступа Л. Н. Вплив поліморфізму генів $\beta 1$ адренорецепторів та а-субодиниці g-білка на ризик і лише у 53,6 \% чоловіків. Запаморочення відзначали 44,6 \% жінок, а серед чоловіків цей показник становив 15,9\%. Аналогічні закономірності характерні для кардіалгій, які відзначали 34,8 \% хворих жіночої статі і лише 14,5 \% чоловіків.

Висновки. Гіпертонічна хвороба ІІ стадії достовірно погіршує якість життя пацієнтів, що проявляється зниженням показників як фізичного (особливо рольового функціонування, зумовленого фізичним станом, інтенсивності болю та загального стану здоров'я), так і психологічного станів (особливо життєвої активності та соціального функціонування). При цьому виявлені гендерні особливості, що найвиразніше спостерігали у параметрах болю, рольового фізичного, рольового емоційного та соціального функціонування.

розвитку аліментарного ожиріння (огляд літератури) / Л. Н. Приступа, І. О. Дудченко // Журнал клінічних та експериментальних медичних досліджень. - 2013. - Т. 1, № 3. - C. 285-291.

6. Pulse pressure and nocturnal fall in blood pressure are predictors of vascular, cardiac and renal target organ damage in hypertensive patients (LOD-RISK study) / L .Garcha-Ortiz, M. A. Gymez-Marcos, J. Marthn-Moreiras [et al.] // Blood Press Monit. - 2009. - Vol.14. - P. 145-151.

7. Day-night dip and early-morning surge in blood pressure in hypertension: prognostic implications / P. Verdecchia, F. Angeli, G. Mazzotta [et al.] // Hypertension. - 2012. Vol. 60. - P. 34-42.

8. Ware J. E. The MOS 36-item short-form health survey (SF-36). I. Conceptual framework and item selection / J. E. Ware, C. D. Sherbourne // Med. Care. - 1992. - Vol. 30 (6). P. 473-483.

Отримано 04.04.18 